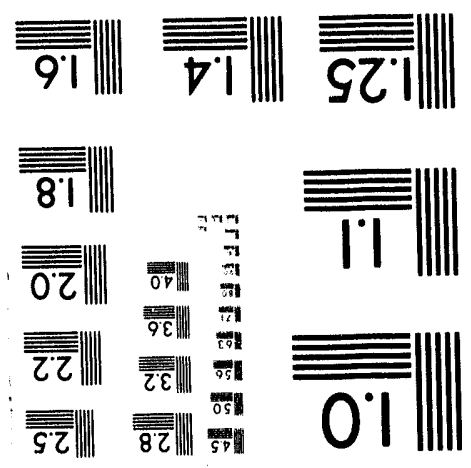



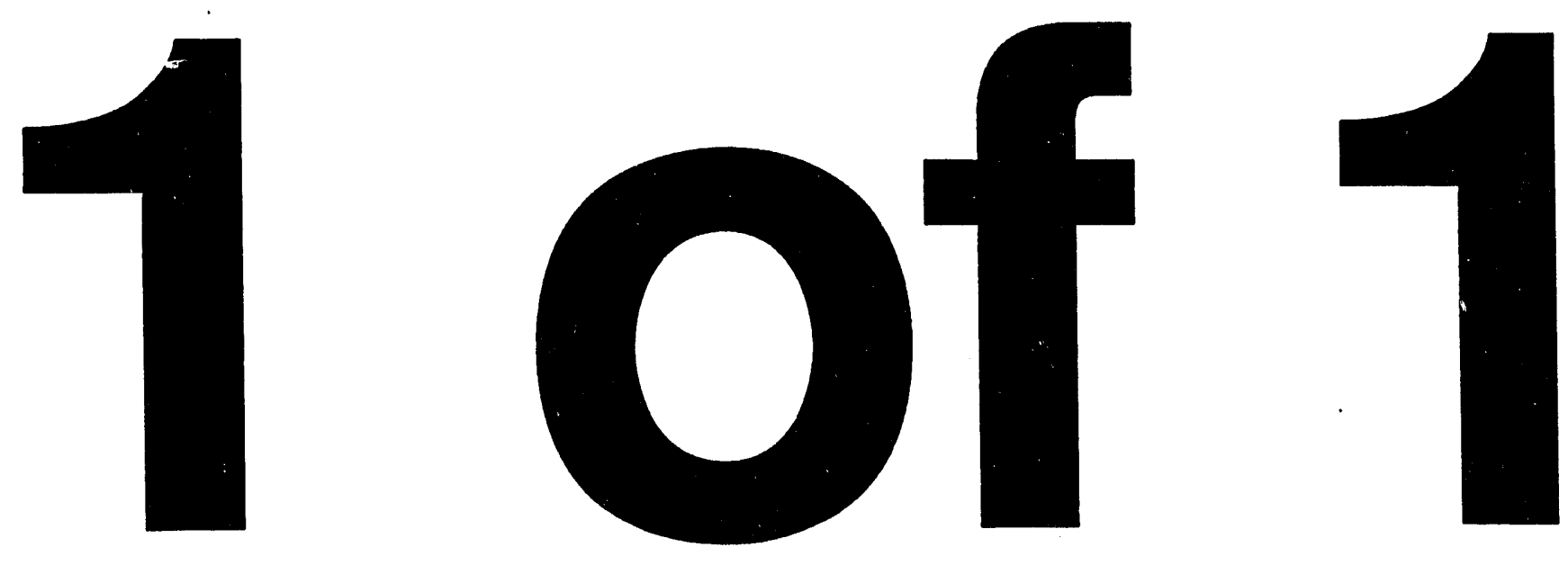


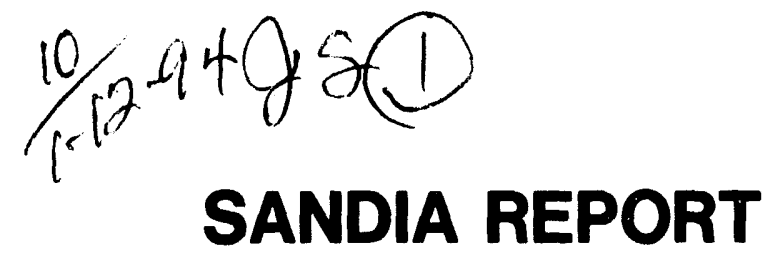

SAND93-2147 $\cdot$ UC -607

Unlimited Release

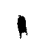

Printed December 1993

\section{Toxicity Evaluation and Hazard Review for 0 -Chlorobenzylidene Malononitrile}

Melecita M. Archuleta, William E. Stocum

Proparod by

Sendla National Leboratorios

Albuquorque, Now Moxico 87185 and Livormore, Callfornia 94550

for the United States Department of Enorgy

under Contract DE-ACO4-04AL85000 
Issued by Sandia National Laboratories, operated for the United States Department of Energy by Sandia Corporation.

NOTICE: This report was prepared as an account of work sponsored by an agency of the United States Government. Neither the United States Government nor any agency thereof, nor any of their employees, nor any of their contractors, subcontractors, or their employees, makes any warranty, express or implied, or assumes any legal liability or responsibility for the accuracy, completeness, or usefulness of any information, apparatus, product, or process disclosed, or represents that its use would not infringe privately owned rights. Reference herein to any specific commercial product, process, or service by trade name, trademark, manufacturer, or otherwise, does not necessarily constitute or imply its endorsement, recommendation, or favoring by the United States Government, any agency thereof or any of their contractors or subcontractors. The views and opinions expressed herein do not necessarily state or reflect those of the United States Government, any agency thereof or any of their contractors.

Printed in the United States of America. This report has been reproduced directly from the best available copy.

Available to DOE and DOE contractors from

Office of Scientific and Technical Information

PO Box 62

Oak Ridge, TN 37831

Prices available from (615) 576-8401, FTS 626-8401

Available to the public from

National Technical Information Service

US Department of Commerce

5285 Port Royal Rd

Springfield, VA 22161

NTIS price codes

Printed copy: A03

Microfiche copy: A01 


\title{
TOXICITY EVALUATION AND HAZARD REVIEW \\ for o-CHLOROBENZYLIDENE MALONONITRILE
}

\author{
Melecita M. Archuleta \\ and \\ William E. Stocum \\ Industrial Hygiene and Toxicology \\ Sandia National Laboratories
}

\begin{abstract}
Ortho-Chlorobenzylidene Malononitrile (CS) is one of a number of riot control agents referred to as tear gas, although it is in fact a particulate suspension. The toxicity of this material has been studied in various detail. The purpose of this study was to review and summarize the literature data available on the toxicity of CS. An extensive literature search on this material was reviewed for the information contained in this report. The results of this evaluation indicate that CS, although a severe mucous membrane and upper respiratory tract irritant, has a low order of systemic toxicity as compared to other irritants of its kind. The physical properties of CS and the unpleasant nature of the symptoms it produces, results in conditions that are intolerable for periods of exposure longer than a minute, at concentrations below which systemic toxic effects are seen. Furthermore, several studies have evaluated the effects of CS in humans and have indicated that while intolerable symptoms come on immediately, removal from the contaminated atmosphere results in disappearance of the effects in minutes. There is no evidence from studies of CS industrial workers that chronic exposure results in any significant toxic effects.
\end{abstract}




\section{Contents}

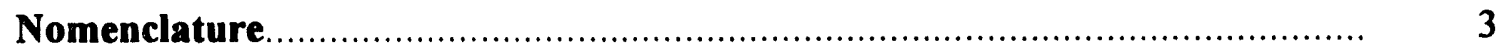

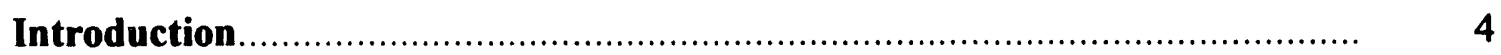

o-Chlorobenzylidene Malononitrile .................................................. 5

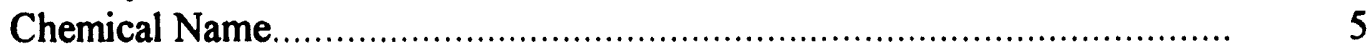

Molecular Formula ............................................................... 5

CAS Number..................................................................... 5

Chemical and Physical Properties...................................................... 5

Exposure Limits...................................................................... 5

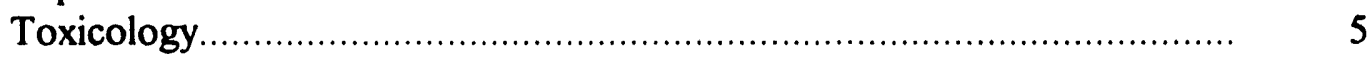

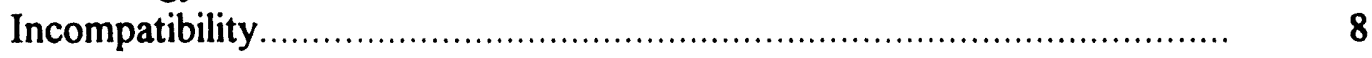

Hazardous Decomposition Products.......................................... 8

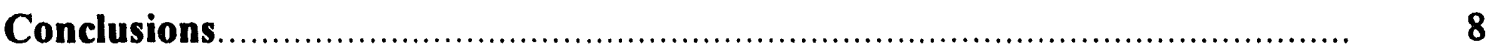

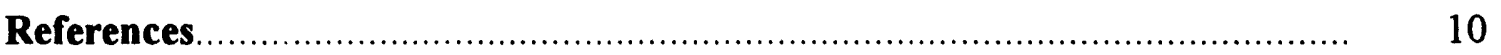

Tables

1. Toxicology Data o-Chlorobenzylidene Malononitrile........................... 6

2. Effects of Exposure to 0-Chlorobenzylidene Malononitrile................... 6 


\section{Nomenclature}

ACGIH

CEIL

$\mathrm{CN}$

CS

$\mathrm{Ct}$

DM

HSDB

IARC

LCtLo

LCt50

LD50

NA

NIOSH

NTP

OSHA

PEL

RTECS

TCLO

TCtLo

TLV

TWA

$\mathrm{g}$
$\mathrm{kg}$
$\mathrm{m}^{3}$
$\mathrm{~min}$.
$\mathrm{mg}$
$\mathrm{ml}$

American Conference of Governmental Industrial Hygienists

Ceiling, the concentration that should not be exceeded during any part of the working exposure.

$\alpha$-Chloroacetophenone

Ortho-Chlorobenzylidene Malononitrile

Exposure dose $\left(\mathrm{mg} \cdot \mathrm{min} . / \mathrm{m}^{3}\right)$ - calculated as the product of the concentration $\left(\mathrm{mg} / \mathrm{m}^{3}\right)$ and time $(\mathrm{min}$.) of exposure.

10-Chloro-5, 10-dihydrophenarsazine

Hazardous Substances Data Bank

International Agency for the Research of Cancer

Lethal-exposure dose-Low $=$ Lowest exposure dose reported to cause death in the population studied.

Lethal exposure dose - Fifty $=$ Exposure dose that leads to death in $50 \%$ of the population studied.

Lethal dose - Fifty $=$ Dose that leads to death in $50 \%$ of the population studied.

information not available

National Institute of Occupational Safety and Health

National Toxicology Program

Occupational Safety and Health Administration

permissible exposure limit

Registry of Toxic Effects of Chemical Substances

Toxic concentration-Low $=$ Lowest concentration that exhibits toxic effects in the population studied

Toxic exposure dose - Low $=$ Lowest Exposure dose that exhibits toxic effects in the population studied.

threshold limit value

time weighted average ( 8 hour)

grams

kilograms

cubic meters

minutes

milligrams

millimeters 


\section{TOXICITY EVALUATION AND HAZARD REVIEW \\ for o-CHLOROBENZYLIDENE MALONONITRILE}

\section{Introduction}

Riot-control agents in the form of obscurant smokes or irritants have long been used in the military and police forces. The purpose of this study is to review and evaluate the toxicity of the riot-control agent ortho-Chlorobenzylidene Malononitrile (CS). OrthoChlorobenzylidene Malononitrile is a white crystalline solid with a pepper-like odor. It is dispersed as a cloud of finely divided particles by means of blowers, explosives, aerosol sprays, or by burning a mixture of the powder and some fuel. It is used in the form of an aerosol as a lacrimating riot control agent or "tear gas" $(1,2)$. Initial studies on the toxicity of CS and other riot control lacrimating agents have indicated that this material is the most effective and the least toxic of three irritants used in this capacity, CS, $\alpha$ chloroacetophenone, (CN) and 10-chloro-5, 10-dihydrophenarsazine(DM). In addition, there is a wide margin of safety between the exposure dose of CS that produces intolerable symptoms in man and that which might be lethal (3).

CS produces erythema (redness) of the eye and severe conjunctivitis (inflammation of the eyes). It has also been shown to produce intense burning of the skin following a large dermal exposure. The most severe and incapacitating effects are felt in the respiratory tract and include coughing, burning of the throat, and chest constriction. Human volunteers in a test exposure chamber have found concentrations greater that $10 \mathrm{mg} / \mathrm{m}^{3}$ in air to be extremely irritating, and intolerable for more than thirty seconds $(4,5,6)$, while the dose which would lead to death in the most susceptible animal species is 200 to 300 times greater (7).

This report summarizes the current chemical and toxicological literature on CS and reports on the health hazards associated with various exposure scenarios. Chemical and physical properties and exposure limits are also given when available. 


\section{G-Chlorobenzylidene Malononitrile}

\section{Chemical Name:} ortho-Chlorobenzylidene Malononitrile (CS)

Molecular Formula (8):

$\mathrm{C}_{10} \mathrm{H}_{5} \mathrm{ClN}_{2}$

\section{CAS Number:} 2698-41-1

Chemical and Physical Properties $(8,9)$ :

Melting Point: $93-95^{\circ} \mathrm{C}\left(199-203^{\circ} \mathrm{F}\right)$

Boiling point: $310-315^{\circ} \mathrm{C}\left(590-599^{\circ} \mathrm{F}\right)$

Flash Point: N/A

Appearance: White powder

Odor: Pepper-like odor

Solubility in Water: Insoluble $\left(0.008 \% @ 25^{\circ} \mathrm{C}\right)$

Log Octanol/water partition coefficient: No data.

Exposure limits (10):

OSHA-PEL: $\quad 0.4 \mathrm{mg} / \mathrm{m}^{3}(0.05 \mathrm{ppm})-\mathrm{CEIL}$; skin ${ }^{\mathrm{a}}$

NIOSH: $\quad 0.4 \mathrm{mg} / \mathrm{m}^{3}(0.05 \mathrm{ppm})-$ CEIL; skin ${ }^{\mathrm{a}}$

ACGIH TLV: $\quad 0.39 \mathrm{mg} / \mathrm{m}^{3}(0.05 \mathrm{ppm})$ - CEIL; skina

a A potential significant contribution to the overall exposure is present by the dermal route. Therefore, dermal exposure should be considered when evaluating exposure limits.

Toxicology: CS acts directly on the mucous membranes to produce irritation, burning, and pain in the eyes, nose, throat, and respiratory tract. This action on the eyes causes lacrimation (tear flow), blepharospasm (tightly closed eyelids), and conjunctivitis (inflammation and redness of the eyes). The most incapacitating effects are felt in the respiratory tract and occurs at CS concentrations of 4.3-6.7 $\mathrm{mg} / \mathrm{m}^{3}$. These effects include sneezing, coughing, salivation, congestion of the nose and wall of the pharynx, chest constriction, and a feeling of suffocation (11). Studies evaluating the toxicity of CS have reported toxic effects (irritation, coughing, sneezing) in humans at an exposure dose of $135 \mathrm{mg} \cdot \mathrm{min} . / \mathrm{m}^{3}$ or a TCLo of $1.5 \mathrm{mg} / \mathrm{m}^{3}$ for a $90 \mathrm{~min}$. exposure (6). This concentration is at least 2 orders of magnitude lower than the lethal concentrations reported in animal studies see Table I, LCtLo and LCt50. 
TABLE I

Summary of Toxicology Data

\begin{tabular}{|c|c|c|c|}
\hline Species & $\begin{array}{c}\text { Oral LD50 } \\
(\mathbf{m g} / \mathbf{k g})\end{array}$ & $\begin{array}{c}\text { Inhalation LCtLo } \\
\left(\mathbf{m g} \cdot \mathbf{m i n} \cdot \mathbf{m}^{\mathbf{3}}\right)\end{array}$ & $\begin{array}{c}\text { Inhalation LCt50 } \\
\left(\mathbf{m g} \cdot \mathbf{m i n}^{\mathbf{c}} / \mathbf{m}^{\mathbf{3}}\right)\end{array}$ \\
\hline rat & 178 & 81,270 & 69,800 \\
\hline mouse & 282 & 55,060 & 70,900 \\
\hline rabbit & 143 & 18,020 & 63,600 \\
\hline guinea pig & 212 & 23,260 & 35,800 \\
\hline monkey & $\mathrm{NA}^{\mathrm{d}}$ & $\mathrm{NA}$ & 123,000 \\
\hline
\end{tabular}

a From: NLM Toxicology Data Network RTECS, (1993).

b From: Ballantyne and Swanston, (1978).

c From: Himsworth, et al., (1971)

d NA = information not available

Acute Exposure: Acute exposures to CS causes headache, eye irritation (with eye watering and burning), burning of the throat, sneezing, coughing, and a constricting sensation in the chest. Table II describes the various concentrations intolerable to select human populations and compares them to the lethal concentration for the most sensitive animal species. These symptoms decrease in minutes upon removal from exposure. Burning of the skin can also occur. This is greatly increased by the presence of moisture with heavy exposures resulting in skin blistering (13).

Chronic Exposure: No long term effects of exposure to reasonable concentrations of CS are known. Epidemiological studies on scientists, training instructors, and industrial workers, working with $\mathrm{CS}$, have shown no evidence of chronic toxic effects due to prolonged or repeated exposures (7). 
TABLE II

Results of Exposure to $\mathrm{CS}^{a}$

\begin{tabular}{|c|l|}
\hline Concentration & \multicolumn{1}{c|}{ Symptoms a } \\
\hline $0.004 \mathrm{mg} / \mathrm{m}^{3}$ & $\begin{array}{l}\text { Smallest concentration detectable by eye } \\
\text { and throat irritation. }\end{array}$ \\
\hline $0.5 \mathrm{mg} / \mathrm{m}^{3}$ & $\begin{array}{l}\text { Concentration which wol Id disperse } \\
\text { unprotected (no respiratory protection) } \\
\text { bystanders in a riot situation. }\end{array}$ \\
\hline $4.0 \mathrm{mg} / \mathrm{m}^{3}$ & $\begin{array}{l}\text { Concentration which would disperse } \\
\text { unprotected active participants in a riot } \\
\text { situation. }\end{array}$ \\
\hline $10 \mathrm{mg} / \mathrm{m}^{3}$ & $\begin{array}{l}\text { Maximum concentration that can be } \\
\text { tolerated for one minute by unprotected } \\
\text { trained troops involved in an exercise or } \\
\text { mission. }\end{array}$ \\
\hline $2500-3500 \mathrm{mg} / \mathrm{m}^{3}$ & $\begin{array}{l}\text { Lethal exposure dose reported to cause } \\
\text { death in the most sensitive animal species, } \\
\text { the guinea pig. }\end{array}$ \\
\hline
\end{tabular}

a From: Himsworth, et al., (1971).

Eye Exposure: $\mathrm{CS}$ is a severe eye irritant with only superficial reversible eye injury seen even with extreme exposures $(14,15)$. Exposure of CS to the eyes of humans results in instantaneous and severe conjunctivitis (inflammation) accompanied by burning and pain that can persist for 2-5 minutes. The conjunctivitis can persist for 25-30 minutes following exposure. Erythema (inflammation and redness) accompanied by blepharospasm (spasmodic winking) is also seen as a result of exposure, and can be accompanied by lacrimation (tearing). This effect was found to persist for up to 15 minutes following exposure $(16,17)$. Those individuals with a pre-existing eye problem such as cataracts and glaucoma may be at increased risk from exposure.

Inhalation Exposure: $\mathrm{CS}$ is a severe mucous membrane and upper respiratory irritant (18). Exposure initially results in a burning sensation in the throat that progresses down the respiratory tract causing moderate to severe coughing. While the concentrations that can be tolerated vary among individuals (see Table II), irritating effects are generally detectable at concentrations of $0.004 \mathrm{mg} / \mathrm{m}^{3}$. This is followed by a constricting sensation throughout the chest and the feeling of 
suffocation or incapacitating respiratory effects (19). Pulmonary edema has also been noted 12 - 24 hours after exposure, in monkeys exposed to $900 \mathrm{mg} / \mathrm{m}^{3}$ for 3 minutes (3). CS exposure of persons with impaired pulmonary function, especially those with obstructive airway disease, may result in exacerbation of symptoms due to its irritant properties.

Oral Exposure: LD50 data for various animal species is given in Table I. However, ingestion of CS powder following deployment is not expected to occur in significant amounts. Oral exposure under these conditions therefore, would result in nausea and vomiting due to the irritating properties of CS $(6,7)$.

Dermal Exposure: CS is a primary skin irritant. Direct exposure of the skin resulted in a burning sensation that is accentuated by moisture such as perspiration, lacrimation or washing of the skin $(6,19)$. Experimental stidies of dermal exposure to high concentrations of pyrotechnically generated $\mathrm{CS}(\mathrm{Ct}=14,040$ $\left.17,700 \mathrm{mg} \cdot \mathrm{min} / \mathrm{m}^{3}\right)$ under conditions of high temperature and humidity have resulted in blistering of the skin (20). These burns, upon removal of the exposure, healed quickly without any permanent scarring. Repeated or prolonged exposure to CS smoke may lead to sensitization dermatitis and persons with pre-existing skin disorders such as dermatitis or open wounds may be more susceptible to the effects of this agent.

Carcinogenicity: No evidence of carcinogenicity has been detected with this compound $(21,22)$. CS is not listed as a carcinogen by NTP, IARC, or ACGIH nor is it regulated as a carcinogen by OSHA.

Reproductive Effects: Rats and rabbits exposed to CS at concentrations of 30, 100 , and $300 \mathrm{mg} \cdot \mathrm{min} / \mathrm{m}^{3} /$ day on days $6-15$ of pregnancy, did not exhibit any reproductive effects. Neither inhalation nor intraperitoneal exposure to CS resulted in any embryolethal or teratogenic effects. $(23,24)$.

Incompatibility: As with most organic materials, contact of CS with strong oxidizers may cause fires and explosion (8).

Hazardous Decomposition Products: As with most organic materials, toxic gases and vapors such as hydrogen chloride, hydrogen cyanide, oxides of nitrogen, and carbon monoxide may be released in a fire involving CS (8). 


\section{Conclusions}

o-Chlorobenzylidene malononitrile is one of the most common training and riot-control lacrimating agents in use. It is a clear white solid that is dispersed as a colorless particulate suspension with an acrid pepper-like smell that is immediately irritating to the eyes and upper respiratory tract. Evaluation of the toxicity of CS indicates that this material is primarily a severe mucous membrane irritant. CS acts directly on the mucous membranes to produce irritation, burning, and pain in the eyes, nose, throat, and respiratory tract. Upon exposure immediate initial effects include lacrimation (tear flow), blepharospasm (tightly closed eyelids), and conjunctivitis (redness and inflammation) of the eyes. The most incapacitating effects are felt in the respiratory tract and includes sneezing, coughing, salivation, congestion of the nose and wall of the pharynx, chest constriction, and a feeling of suffocation. A burning sensation of the skin that is accentuated by moisture can be detected following an acute exposure to CS powder. Repeated skin exposure has been shown to produce sensitization dermatitis. The maximum concentration of CS that has been tolerated by trained military troops without respiratory protection is $10 \mathrm{mg} / \mathrm{m}^{3}$ for less than one minute. This concentration is several orders of magnitude less than the concentration of CS smoke that is capable of producing fatal damage in the most sensitive animal model (approximately $2500-3500 \mathrm{mg} / \mathrm{m}^{3}$ ) whether this is the result of a high acute exposure or a lower chronic exposure. Therefore it is expected, and has been the experience of those working with and using CS, that a man will remove himself from the exposure, if physically able (i.e. not in a locked room, not seriously injured), long before being exposed to incapacitating or lethal doses. 


\section{References}

1. Compton, J.A.F., Military Chemical and Biological Agents: Chemical and Toxicological Properties. The Teleford Press, Caldwell, NJ, p. 237-244, (19 ).

2. Corson, B.B., and Stoughton, R.W., Reaction of Alpha, Beta-Unsaturated Dinitriles. J. Amer. Chem. Soc. 50:2825-2827, (1928).

3. Striker, G.E., Streett, C.S., Ford, D.F., Herman, L.H., and Helland, D.R., $A$ Clinico-pathologic Study of the Effects of Riot-Control Agents on Monkeys: IV.oChlorobenzylidene Malononitrile (CS) Grenade. Edgewood Arsenal Technical Report, EATR 4071, Medical Research Laboratory, Edgewood Arsenal, January (1967).

4. US Department of Health and Human Services and US Department of Labor, Occupational Health Guideline for o-Chlorobenzylidene Malononitrile. in Occupational Health Guidelines for Chemical Hazards, September (1978).

5. Punte, C.L., Weiner, J.T., Ballard, T.A. and Wilding, J.L., Toxicologic Studies on oChlorobenzylidene Malononitrile. Toxicol. Appl. Pharmacol. 4(5): 656-662, (1962).

6. Punte, C.L., Owens, E.J., and Gutentag, P.J., Human Exposures to (ortho)Chlorobenzylidene Malononitrile. Arch. Environ. Health 6: 366-374, (1963).

7. Himsworth, S.H., Black, D.A.K., Crawford, T., et. al., Report of the Enquiry into the Medical and Toxicological Aspects of CS (Orthochlorobenzylidene Malononitrile) Part II. London: Her Majesty's Stationery Office, Cmnd 4775, (1971).

8. Occupational Health Services Inc., (Ortho)-Chlorobenzylidene Malononitrile. Material Safety Data Sheet, (1993).

9. American Conference of Governmental Industrial Hygienists, Documentation of Threshold Limit Values and Biological Exposure Indices. Fifth Edition, (1975).

10. American Conference of Governmental Industrial Hygienists, Guide to Occupational Exposure values. ISBN:0-936712-98-8, (1992).

11. Directorate of Medical Research, A Special Summary Report on the Toxicology of $C N, C S$, and DM. US Army Edgewood Arsenal, Chemical Research and Development Laboratories, May (1991).

12. National Library of Medicine Toxicology Data Network, Registry of Toxic Effects of Chemical Substances (RTECS). TOXNET, (1993). 
Toxicology Evaluation and Hazard Review

o-Chlorobenzylidene Malononitrile

13. AAI Corporation, TG Guard Property Protection System - A User's Introduction to the Characteristics of Irritant Agents. January (1971).

14. Ballantyne, B., Gassard, M.F., Swanston, D.W., and Williams, P., The Ophthalmic Toxicology of o-Chlorobenzylidene Malononitrile (CS). Arch. Toxicol. 32: 149-168, (1974).

15. Grant, W.M., o-Chlorobenzylidene Malononitrile. Toxicology of the Eye, Third Ed C.C. Thomas, Springfield, IL, p.209. (1986).

16. Ballantyne, B., and Swanston, D.W., The Irritant Potential of Dilute Solutions of Ortho-Chlorobenzylidene Malononitrile (CS) on the Eye and Tongue. Acta.

Pharmacol. (Kbh.) 32: 266-277, (1973).

17. Gutentag, P.J., Hart, J., Owens, E.J., Punte, C.L., The Evaluation of CS Aerosols as Riot-Control Agents in Man. U.S. Army Chemical Corps Research and Development Command, Chemical Warfare Laboratories, Army Chemical Center, MD, CWLR 2365, (1960).

18. Ballantyne, B., Callaway, S., Inhalation Toxicology and Pathology of Animals Exposed to o-Chlorobenzylidene Malononitrile (CS). Med. Sci. Law 12: 43-65, (1972).

19. Craig, F.N., Blevins, W.V., and Cummings, E.G., Breathing Patterns During Human Exposure to CS. Chemical Warfare Laboratory Report, CWLR-2399, US Army Chemical Corps Research and Development Command, Chemical Warfare Laboratories, Army Chemical Center, MD, June (1960).

20. Hellreich, A., Goldman, R.H., Bottiglieri, N.G., and Weimer, J.T., The Effects of Thermally-Generated CS Aerosols on Human Skin. Edgewood Arsenal Technical Report, EATR 4075, Medical Research Laboratory, Edgewood Arsenal, January (1967).

21. von Däniken, A., Friederich, Urs., Lutz, W.K., and Schlatter, C., Tests for Mutagenicity in Salmonella and Covalent Binding to DNA and Protein in the Rat by the Riot Control Agent, o-Chlorobenzylidene Malononitrile. Archives of Toxicol. 49: 15-27, (1981).

22. Schmid, E. and Bauchinger, M., Analysis of the Aneuploidy Inducing Capacity of 2Chlorobenzylidene Malononitrile (CS) and Metabolites in V79 Chinese Hamster Cells. Mutagenesis 6(4): 303-305, (1991). 
23. Upshall, D.G., Effects of 0-Chlorobenzylidene Malononitrile (CS) and the Stress of Aerosol Inhalation upon Rat and Rabbit Embryonic Development. Toxicol. Appl. Pharmacol. 24(1): 45-59, (1973).

24. Ballantyne, B., and Swanston, D.W., The Comparative Acute Mammalian Toxicity of 1-Chloroacetophenone (CN) and 2-Chlorobenzylidene Malononitrile (CS). Arch. Toxicol. 40:75-95, (1978).

25. National Library of Medicine Toxicology Data Network, Hazardous Substances Data Bank (HSDB), TOXNET. (1993). 
Toxicology Evaluation and Hazard Review

o-Ciulorobenzylidene Malononitrile

\section{DISTRIBUTION:}

1 8523-2 Central Technical Files

57141 Technical Library

17151 Technical Publications

10 7613-2 Document Processing for DOE/OSTI

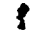

1 DOE/TSD/TSB R.H. Richey

$10323 \quad$ L.M. Weston

$1 \quad 1832 \quad$ L.M. Maestas

$16411 \quad$ T.M. Hake

$17711 \quad$ M.M. Archuleta

$1 \quad 7711 \quad$ C.J. Pigg

17712 W.E. Stocum

19603 E.R. Hoover

19611 C.J. Greenholt

$19611 \quad$ S.H. Scott

$19611 \quad$ M.R. Kodlick

$19612 \quad$ H.J. Abeyta

$19612 \quad$ R.C. Cranfill

19612 G.W. Crowder

19613 J.J. Roesch

19613 J.K. Deuel

19614 W.F. Hartman 

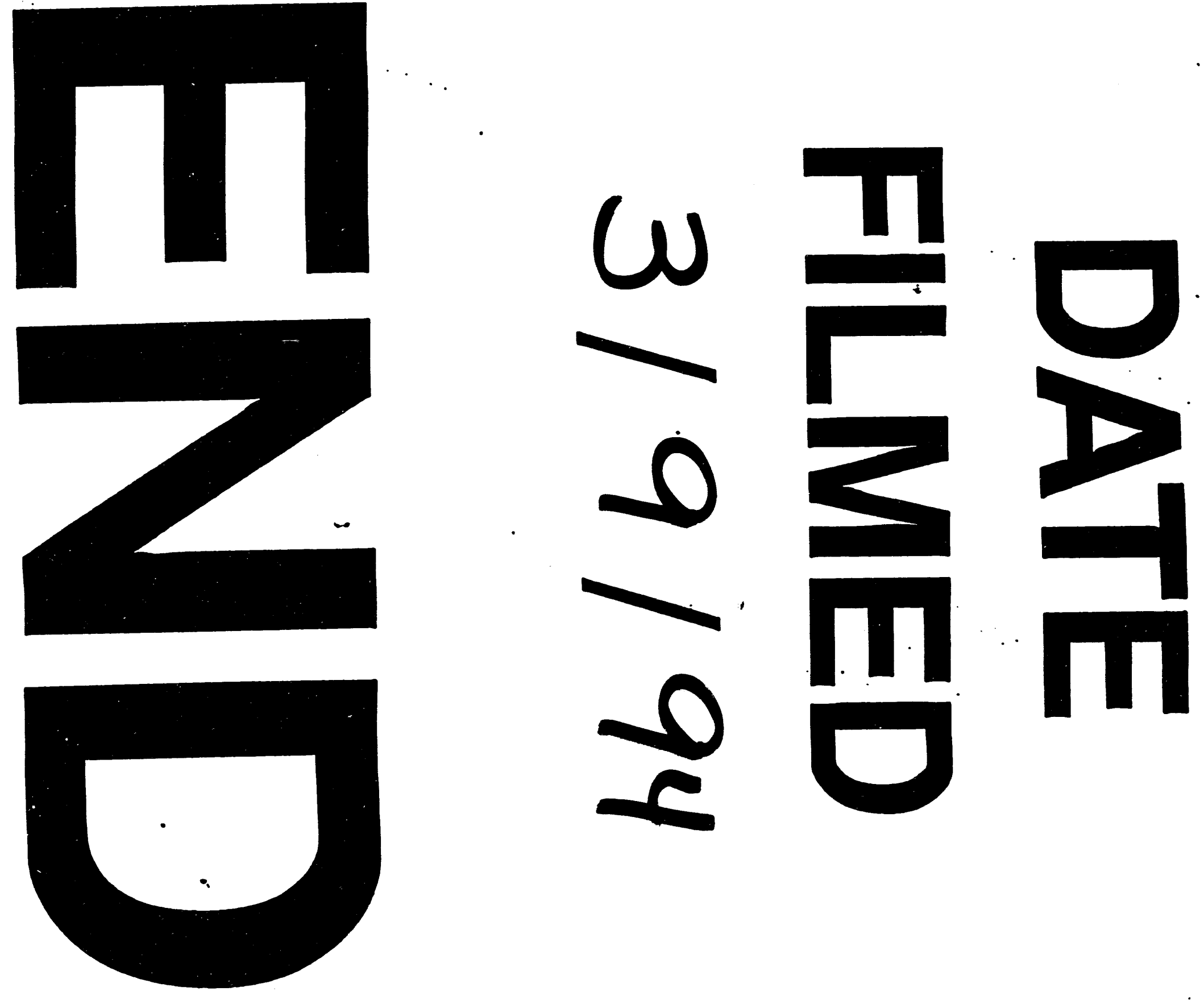
